УДК 631.95:631.147(477.53)

(C) 2017

Горб О. О., кандидат сільськогосподарських наук, доцент,

Чайка T. О., кандидат економічних наук,

Яснолоб І. О., кандидат економічних наук

Полтавська державна аграрна академія

\title{
ВИКОРИСТАННЯ СИДЕРАЛЬНИХ КУЛЬТУР ЯК ВІДНОВЛЮВАНОГО ДЖЕРЕЛА ЕНЕРГІЇ В ОРГАНІЧНОМУ ЗЕМЛЕРОБСТВІ
}

\section{Рецензент - доктор сільськогосподарських наук, професор П. В. Писаренко}

У статті обтрунтовано актуальність використання сидеральних культур в органічному землеробстві. Виділено особливості їх використання для певних сільськогосподарських культур.

Доведено переваги від використання зелених добрив і надано пропозиції щуодо їх використання сільськогосподарським господарствам $і$ фермерам. Наведено сидеральні культури в овочівництві та їх агротехнологічні особливості.

Обтрунтовано форми кормовиробництва та застосування зелених добрив. Наведено кліматичні, трунтові та організаційно-економічні умови використання сидеральних культур.

Ключові слова: органічне землеробство, сидеральні культури, сільськогосподарське виробництво, агротехнології, відновлювальні джерела енергіï.

Постановка проблеми. Сучасний стан сільського господарства та сільськогосподарських угідь вимагає негайного втручання у систему ведення сільськогосподарського виробництва 3 метою використання екологічно безпечних і енергетично заощадливих технологій. Однією з таких перспективних та актуальних сьогодні систем $є$ органічне землеробство, досвід ведення якого поширений на території всієї України, а його продукція користується зростаючим попитом не лише серед населення країни, а й за кордоном.

Аналіз останніх досліджень і публікацій, у яких започатковано розв'язання проблеми. Дослідження агроекологічних особливостей органічного землеробства започатковані в працях представників української школи фізичної економії: С. Подолинського, В. Вернадського та продовжені І. Овсинським, М. Руденком, С. Антонцем, В. Писаренком, В. Кисілем та ін. Сьогодні екологічні проблеми землеробства досліджуються такими науковцями: В. Горщар, О. Конопльов, В. Мазур, Ю. Манько, С. Паламарчук, І. Примак та ін. [3].

Значну увагу у системі органічного землеробства приділяють сидеральним культурам. Термін «сидерація» вперше запропонував у XIX ст. французький вчений Ж. Віль. Заробку (повну або часткову) у грунт надземної маси спеціально висіяних рослин називають «сидерацією», а саму культуру - сидератом. У перекладі 3 латини означає «зірковий, променевий», тобто добриво, яке можна отримати шляхом перетворення сонячної енергії [1].

Метою статті $\epsilon$ дослідження особливостей використання сидеральних культур в органічному землеробстві, як відновлювального джерела енергіï.

Матеріали і методи досліджень. У ході дослідження методологічною базою $є$ наступні наукові методи: діалектичний (для визначення особливостей використання сидеральних культур в органічному землеробстві), аналізу і синтезу (для виявлення переваг використання зелених добрив), теоретичний пошук i абстрактнологічний (для пропозицій щодо вирощування сидеральних культур), порівняння (для напрямів застосування визначення сидеральних), моделювання (для побудови форм кормовиробництва та застосування зелених добрив).

Результати досліджень. Сидерати - рослини, які вирощують перед посадкою основної культури, для збагачення грунту корисними елементами. Вони відновлюють запаси гумусу, покращують структуру, підвищують родючість верхнього орного шару. Ці рослини невибагливі, і холодостійкі, тому їх можна висаджувати навіть ранньою весною і восени. У деяких областях сидерати садять на початку жовтня, і до настання холодів вони встигають наростити необхідну зелену масу. Способів застосування цього «зеленого добрива» безліч. Даний тип рослин знижує кислотність грунту, допомагає накопичувати в верхніх горизонтах корисні макроелементи, прискорює мікробіологічні процеси [2].

Вважаємо, що під сидерацією слід розуміти заробку не тільки надземної частини, а і кореневої системи, тобто усієї рослинної маси.

Зазвичай трав'янистий покрив спочатку скошується, потім проводиться закладення рослинних залишків у грунт. 


\section{СІЛЬСЬКЕ ГОСПОДАРСТВО. РОСЛИННИЦТВО}

Кореневі залишки та закладена у грунт надземна маса рослин є джерелом енергії для грунту та кормом для грунтових організмів; у результаті стимулюється життєдіяльність мікроорганізмів і стабілізується грунтова структура.

Бобові сидератні культури містять значну частку азоту, який може використовуватися подальшими культурами.

Більшість сидератних культур підвищують засвоюваність мінеральних речовин, що містяться у грунті за допомогою своїх кореневих виділень.

Сидератні культури покривають грунт і тим самим подавляють ріст бур'янів і захищають його від шкідливих метеорологічних впливів.

Рослини у фазі цвітіння є джерелом поживних речовин для корисних комах.

Під час обробітку сидератів поживні речовини (в основному азот), «консервуються», у наслідок чого не вимиваються з грунту. Вимивання поживних речовин небажано, в разі вимивання вони стають недоступними для наступних культур, крім того, викликають забруднення грунтових вод, закритих водоймищ, річок, озер і морів.

Таким чином, зелені добрива:

- збагачують грунт азотом (у разі застосування бобових рослин в якості сидератів);

- збагачують грунт органічним матеріалом (вуглець);

- витягають 3 глибинних шарів грунту поживні речовини та переводять їх у легко засвоювану рослинами форму;

- фіксують необхідні рослині поживні речовини в легко засвоюваній (у вигляді розчину) формі;

- перешкоджають вимиванню поживних речовин;

- розпушують глибинні шари грунту за допомогою кореневої системи рослин.

Підбір культур для зелених добрив залежить від кліматичних умов, типу грунту, від потреб і можливостей господарства. Слід зазначити, що велике значення при цьому має розмір кореневої системи, а також іï здатність фіксувати азот.

Виходячи 3 типу господарства, бажань і можливостей фермера, сидеральні культури можуть вирощуватися:

- щорічно, що $є$ найефективнішим видом їх використання, оскільки у цьому випадку збагачення грунту відбувається протягом тривалого часу. Недоліком цього способу є те, що сидеральні культури не дають товарної продукції. Але як правило, цей недолік повністю компенсується протягом наступних років підвищенням врожаю за рахунок сидерації і дуже низьких витрат на добрива, боротьбу з бур'янами та шкідниками;

- в якості пожнивної культури, причому можуть вирощувати як озимі, так і ярі культури на зелене добриво. Пожнивні культури на сидерат на практиці є найбільш розповсюдженим видом зеленого добрива. 3 цією метою після збирання основної культури висівають різні рослини й травосуміші в період з липня по жовтень;

- в якості проміжної культури, що висівається 3 початку лютого; найбільш підходящими культурами є гірчиця і шпинат. Після прибирання цих культур на зелене добриво грунт обробляється та проводиться посів основної культури;

- в якості підпокривної культури в багаторічній або однорічній основній культурі.

Підпокривні культури на зелене добриво висіваються в міжряддях зростаючих культур, насамперед таких, як смородина, агрус, ожина, а також кукурудза, різні види капусти і змішаних культур. Для цієї мети використовують конюшину підземну (Trifolium subterraneum), конюшину білу (Trifolium repens), а також валеріанеллу овочеву (салат польовий, Valeriapella locusta).

Залежно від виду сівозміни сидерати застосовуються як у вигляді проміжної культури, так і у вигляді блоку «головна культура/зелений пар» (табл. 1) [4].

В органічному землеробстві конюшина та злакові трави вирощуються переважно в змішаних посівах. Вони 3 високою ефективністю доповнюють один одного. Потужна, дрібно розгалужена коренева система злакових культур, у поєднанні зі спроможністю бобових фіксувати атмосферний азот, сприяють формуванню родючого грунту. Застосування суміші виключає багато проблем під час годування тварин (обмежуючи можливість утворення газів і спучування). Через значні кормові переваги тварини їх їдять з більшою охотою.

Виробництво кормів і зелених добрив займає провідне місце в органічному землеробстві, оскільки воно є:

- основою системи удобрення грунту;

- проміжною ланкою між рослинництвом i тваринництвом.

Досягти значної продуктивності у тваринництві можна лише за високої якості та достатньої кількості кормів.

Найважливішими кормовими рослинами у сівозмінах в органічному землеробстві $€$ конюшина, злакові культури та люцерна, які використовуються в якості однорічних і багаторічних культур в залежності від спрямованості господарства (табл. 2). 


\section{1. Зелені добрива в овочівнищтві}

\begin{tabular}{|c|c|c|c|c|}
\hline Культура & $\begin{array}{c}\text { Норма } \\
\text { висіву } \\
(г / 0,1 \text { га) }\end{array}$ & \begin{tabular}{|c|} 
Час \\
культивації \\
(тиждень)
\end{tabular} & $\begin{array}{c}\text { Глибина } \\
\text { висіву } \\
\text { (см) } \\
\end{array}$ & Примітки \\
\hline \multicolumn{5}{|c|}{ Ранньовесняний висів } \\
\hline $\begin{array}{c}\text { Фацелія } \\
\text { (початок травня) }\end{array}$ & 200 & $6-9$ & $1-1,5$ & $\begin{array}{c}\text { Кормова база бджіл, інтенсивний розвиток } \\
\text { кореневої системи, не є морозостійкою }\end{array}$ \\
\hline Боби кінські & 1500 & $6-9$ & $8-10$ & Морозостійка культура (рання сівба) \\
\hline Шпинат & $300-500$ & $4-7$ & $1-2$ & Морозостійка культура (рання сівба) \\
\hline \multicolumn{5}{|c|}{ Піврічне або цілорічне зелене добриво (висів з березня до середини серпня) } \\
\hline $\begin{array}{c}\text { Конюшина } \\
\text { олександрійська }\end{array}$ & 300 & $6-9$ & $1-2$ & $\begin{array}{c}\text { Неморозостійка культура } 3 \text { прискореним } \\
\text { темпом зростання } \\
\end{array}$ \\
\hline $\begin{array}{l}\text { Віка з горохом і } \\
\text { вівсом }\end{array}$ & 2000 & $8-12$ & $3-4$ & Ефективна суміш \\
\hline \multicolumn{5}{|c|}{ Незимостійкі додаткові посіви (висів до початку вересня) } \\
\hline Чина з горохом & $1500-2500$ & $6-9$ & $3-5$ & $\begin{array}{c}\text { Використовується як зелена маса, а також } \\
\text { для підсіву до капусти, кукурудзи, є гарним } \\
\text { азотофіксатором } \\
\end{array}$ \\
\hline Віка & 1000 & $6-8$ & $3-4$ & $\begin{array}{c}\text { Добре переносить ранні морози, гарний } \\
\text { азотофіксатор }\end{array}$ \\
\hline Віка з вівсом & 600 i 400 & $8-12$ & $3-4$ & $\begin{array}{c}\text { Карбонатні грунти, уповільнений розвиток } \\
\text { на початковій стадії } \\
\end{array}$ \\
\hline $\begin{array}{l}\text { Люпин гіркий (до } \\
\text { початку серпня) }\end{array}$ & 1800 & $9-10$ & $2-3$ & $\begin{array}{c}\text { Рослина, що глибоко укорінюється, } \\
\text { високоефективна в якості попередника, } \\
\text { підходить для вирощування на кислих } \\
\text { грунтах } \\
\end{array}$ \\
\hline Фацелія & $150-200$ & $6-9$ & $1-1,5$ & $\begin{array}{c}\text { Кормова база бджіл, інтенсивний розвиток } \\
\text { кореневої системи }\end{array}$ \\
\hline Редька олійна & 300 & $5-8$ & $2-3$ & $\begin{array}{c}\text { Дуже ефективна рослина з глибоким } \\
\text { укоріненням }\end{array}$ \\
\hline Гірчиця посівна & 300 & $3-5$ & $1-2$ & $\begin{array}{c}3 \text { прискореними типами зростання, помірна } \\
\text { норма висіву, у сівозміні розміщати не } \\
\text { перед капустою будь-яких видів, корисно } \\
\text { розміщати перед злаками }\end{array}$ \\
\hline \multicolumn{5}{|c|}{ Зелене добриво на зимівлю (посів до середини жовтня) } \\
\hline Віка волохата & 800 & \multirow{4}{*}{$\begin{array}{l}\text { до кінця } \\
\text { квітня }\end{array}$} & $1-3$ & Маловимоглива культура, азотофіксатор \\
\hline $\begin{array}{l}\text { Віка волохата i } \\
\text { інкарнатна } \\
\text { конюшина }\end{array}$ & 400 i 150 & & $1-3$ & $\begin{array}{c}\text { Низькорослий зимовий трав'яний покрив } 3 \\
\text { високим вмістом азоту }\end{array}$ \\
\hline Віка волохата і жито & 400 i 600 & & $1-3$ & $\begin{array}{c}\text { Ефективно сприяє відновленню родючості } \\
\text { грунту }\end{array}$ \\
\hline Жито & 1800 & & $1-3$ & Ефективна за пізньої осінньої сівби \\
\hline \multicolumn{5}{|c|}{ Підпокривні культури } \\
\hline Конюшина повзуча & $150-250$ & \multirow{2}{*}{$\begin{array}{l}\text { до кінця } \\
\text { квітня }\end{array}$} & $0-1$ & $\begin{array}{c}\text { Швидко прикриває грунт, стійкий до } \\
\text { витоптування }\end{array}$ \\
\hline Конюшина підземна & $400-600$ & & $1-2$ & $\begin{array}{c}\text { Густий травостій, стійкий до витоптування, } \\
\text { відмерзає }\end{array}$ \\
\hline
\end{tabular}

Частина фермерів вважає, що сидерати не повинні закладатися в грунт, а тільки скошуватися, причому до цвітіння, а потім підрізатися плоско- різом на глибині 2-5 см. Молоді бур'яни можна підрізати плоскорізом і без попереднього скошування. 


\section{2. Форми кормовиробництва та застосування зелених добрив}

\begin{tabular}{|c|c|}
\hline Методи використання & Види рослин \\
\hline \multicolumn{2}{|c|}{ Багаторічне кормовиробництво } \\
\hline Конюшиново-злакова суміш & $\begin{array}{l}\text { Конюшина лугова, райграс багаторічний, конюшина } \\
\text { повзуча, різні злакові трави }\end{array}$ \\
\hline Люцерно-злакова суміш & Люцерна, різні злакові трави \\
\hline \multicolumn{2}{|c|}{ 1,5-річне кормовиробництво або зелений пар (осінній висів) } \\
\hline Конюшиново-злакова суміш & Конюшина лугова, райграс італійський \\
\hline \multicolumn{2}{|c|}{ Однорічна система кормовиробництва або зелений пар (весняний висів) } \\
\hline Конюшиново-злакова суміш & $\begin{array}{l}\text { Конюшина перевернута, конюшина олександрійська, } \\
\text { райграс однорічний }\end{array}$ \\
\hline Зелений пар & Люпин, боби (покривна культуру) \\
\hline $\begin{array}{l}\text { Кормові рослини з високим вмістом } \\
\text { обмінної енергії }\end{array}$ & $\begin{array}{l}\text { Кормовий буряк, кукурудза на силос, суміш зернових } \\
\text { культур з горохом }\end{array}$ \\
\hline \multicolumn{2}{|c|}{ Озимі проміжні культури } \\
\hline Суміш люцерни та злаків, еспарцет & Віка, конюшина інкарнатна, райграс італійський \\
\hline Суміш віки та жита & Віка та жито \\
\hline \multicolumn{2}{|c|}{ Повторні культури (після озимих проміжних культур) } \\
\hline Бобові, хрестоцвіті, турнепс, різні злаки & Боби, горох, річна вика \\
\hline \multicolumn{2}{|c|}{ Літні проміжні культури } \\
\hline Підпокривні культури & $\begin{array}{l}\text { Конюшина повзуча, люцерна, конюшина підземна, } \\
\text { райграс багаторічний }\end{array}$ \\
\hline ультури пожнивного в & Крупностебельні бобові, хрестоцвіті, райграс однорі \\
\hline
\end{tabular}

Зелене добриво є доступним, постійно відновлюваним джерелом органічної речовини. За даними наукових досліджень, загортання в грунт 20-30 т/га зеленої маси сидератів забезпечує ефект, рівноцінний внесенню аналогічної кількості гною. При цьому витрати енергії на вирощування сидеральної культури менші у 2,5 рази.

Висновки 3 даного дослідження і перспективи подальших розвідок у даному напрямі. Цінність і важливість сидеральних культур не обмежується лише властивістю чудового замінника традиційних органічних добрив. У сучасних умовах поглиблення спеціалізації приватних господарств і концентрації сільськогосподарського виробництва відбувається скорочення періоду ротації сівозмін, високе насичення одновидовими або близькими за біологічними властивостями культурами, що призвело до певного напруження фітосанітарного стану в агроценозах. Тому особливого значення для ефективності сівозмін і підтримання родючості грунту набувають

\section{БІБЛІОГРАФІЯ}

1. Методичні рекомендації з основ органічного землеробства для фермерів (досвід ПП «Агроекологія») / [Писаренко П. В., Антонець А. С., Писаренко В. М. та ін.]. - Полтава : ФОП Гонтар O. B., 2013. $-63 \mathrm{c}$.

2. Сидерати: кращі культури, посів, закладення навесні і восени [Електронний ресурс]. - Режим доступу : https://www.vsadu.in.ua/2016/06/krashhi- сидеральні культури.

Доцільно відзначити, що обираючи ту чи іншу сидеральну культуру, потрібно враховувати кліматичні, грунтові та організаційно-економічні умови господарства. Особливу увагу звертати на насінництво, оскільки вартість насіння становить основну статтю витрат під час виробництва зеленого добрива.

Не сприяє поширенню сидерації, відсутність належного наукового обгрунтування доцільності впровадження такого заходу та недостатній рівень його пропаганди серед керівників і спеціалістів господарств. Широке використання сидеральних культур підвищує ефективність природокористування, сприяє підвищенню родючості грунту, отриманню з одиниці площі більшої кількості продукції. Крім того, сидерація відчутно покращує екологічну ситуацію, яка стає в наш час однією з життєво важливих проблем.

syderaty.html.

3. Чайка T. О. Розвиток виробництва органічної продукції в аграрному секторі економіки України : монографія / Т. О. Чайка. - Донецьк : Вид-во «Ноулідж», 2013. - 320 с.

4. Чайка Т. О. Зелені добрива - сидерати в органічному землеробстві / Т. О. Чайка, С. В. Пономаренко // Аграрний бюлетень. - 2015. - №54. - С. 25-31. 